\title{
Mechanisms of Endothelial Protection by Natural Bioactive Compounds from Fruit and Vegetables
}

\author{
BERNARDITA MONSALVE ${ }^{1}$, ANIBAL CONCHA-MEYER ${ }^{2}$, IVÁN PALOMO ${ }^{1,2}$ and EDUARDO FUENTES ${ }^{1,2,3}$ \\ ${ }^{1}$ Platelet Research Laboratory, Department of Clinical Biochemistry and Immunohematology, \\ Faculty of Health Sciences, Interdisciplinary Excellence Research Program on Healthy Aging \\ (PIEI-ES), Universidad de Talca, Postal Code 3460000, Casilla 747, Talca, Chile \\ ${ }^{2}$ Centro de Estudios en Alimentos Procesados/CEAP, CONICYT-Regional, Gore \\ Maule, R09I2001, Postal Code 3460000, Casilla 747, Talca, Chile \\ ${ }^{3}$ Núcleo Científico Multidisciplinario, Universidad de Talca, Postal Code 3460000, Casilla 747, Talca, Chile
}

Manuscript received on August 2, 2016; accepted for publication on December 5, 2016

\begin{abstract}
The endothelium is fundamental for the regulation of vascular tone and structure. Under disease conditions, including the presence of cardiovascular disease risk factors, the endothelium loses its protective role and becomes a proatherosclerotic structure. In this article we searched for strategies from PUBMED and Science Direct databases using the following key words: endothelium, natural bioactive compounds, polyphenols and cardiovascular diseases. The search was restricted to english language papers. Studies have identified the contribution of diet to the risk of developing cardiovascular diseases. In this context, high intakes of fruit and vegetables are associated with the decrease of cardiovascular diseases. Thus the most important fruit/vegetables and bioactive compounds to prevent endothelial diseases are berries, apples, virgin olive oil, tomatoes, soybeans, and polyphenols, carotenoids and unsaturated fatty acids, respectively. The bioactive compounds from fruit and vegetables provide endothelial protection through the following mechanisms: improved eNOS/NO bioavailability, attenuates oxidative stress, inhibited NF$\kappa \mathrm{B}$ pathway and decreased cell adhesion molecules expression. In this article natural bioactive compound mechanisms of endothelium protection are thoroughly reviewed.
\end{abstract}

Key words: endothelium, natural bioactive compounds, polyphenols, cardiovascular diseases.

\section{INTRODUCTION}

Heart and blood vessel damage are commonly known as cardiovascular diseases (CVD) (i.e., acute myocardial infarction, cerebrovascular

Correspondence to: Eduardo Fuentes

E-mail: edfuentes@utalca.cl

Iván Palomo

E-mail: ipalomo@utalca.cl

* Contribution to the centenary of the Brazilian Academy of Sciences. disease and peripheral arterial thrombosis). CVD are responsible for approximately $30 \%$ of deaths worldwide and cause more than 15 million deaths in the world each year (Palomo et al. 2007, Bautista et al. 2006). Among the main risk factors for CVD (RFCVD) are cigarette smoking, elevated blood pressure, elevated serum total cholesterol and diabetes, among others (Icaza et al. 2009, Mujica et al. 2008, Palomo et al. 2006). In addition, these RFCVD contribute to dysregulated endothelium 
function (Palomo et al. 2003, Cai and Harrison 2000, Versari et al. 2009).

The endothelium is recognized as a crucial homeostatic organ, fundamental for vascular tone and structure regulation. Under disease conditions, including the presence of RFCVD, the endothelium undergoes functional and structural alterations, thus losing its protective role and becoming a proatherosclerotic structure (Versari et al. 2009, Taddei et al. 2003). Alteration in endothelial function precedes the development of morphological atherosclerotic changes and can also contribute to wound development and later clinical complications (Deanfield et al. 2007). Therefore, endothelial dysfunction is a well-established response to RFCVD and precedes the development of CVD (Hadi et al. 2005).

The Framingham Heart Study first identified the contribution of diet and sedentary lifestyles to the risk of cardiovascular disease (O'Donnell and Elosua 2008). Moreover, high intakes of fruit and vegetables were associated with a decrease in RFCVD (Liu et al. 2000). Since natural bioactive compounds from fruit and vegetables present CVD prevention properties, they could be directly associated with endothelial protection (Dauchet et al. 2006). In this context, this article reviews different natural bioactive compound mechanisms of endothelium protection.

\section{MATERIALS AND METHODS}

SEARCH STRATEGY. PUBMED and Science Direct databases were researched using the following key words: endothelium, natural bioactive compounds, polyphenols, and cardiovascular diseases.

INCLUSION CRITERIA. The inclusion criteria considered the english language and year of paper's publication.

EXCLUSION CRITERIA. Only papers with abstract topics on cardiovascular diseases per se, or in relation with either (1) endothelium or (2) natural bioactive compounds were selected.

\section{ENDOTHELIAL FUNCTION}

The endothelium corresponds to the inner lining of blood vessels, being the largest organ in the human body. Endothelial cells are critical in the regulation, maintenance and control of cardiovascular functions, which occurs through the release of various molecules with antithrombotic activity that can inhibit platelet adhesion, coagulation and regulate the fibrinolytic system (Aird 2007). Moreover, the endothelial cells have several receptors for vasoactive substances (vasodilator and vasoconstrictor). Some mediators of inflammation such as $\mathrm{C}$ - reactive protein (CRP), IL-6, intercellular adhesion molecule 1 (ICAM$1)$, vascular cell adhesion molecule 1 (VCAM-1), have been regarded as useful predictive markers of endothelial dysfunction in atherosclerosis, whereas other biomarkers (matrix metalloproteinase-9 and IL-18) have been associated with plaque vulnerability (Casas et al. 2014).

The vascular endothelium is the primary site of dysfunction in many diseases, particularly cardiovascular in patients with RFCVD (Heitzer et al. 2001). Endothelial dysfunction expresses adhesion molecules on cell surfaces and synthesizes plasma proteins such as von Willebrand factor (vWF) that are involved in platelet adhesion during thrombosis and inflammation (Kanaji et al. 2012, Etingin et al. 1993, Palomo et al. 2011).

The endothelial dysfunction allows increased platelet adhesion to endothelial cells, which is the first step in platelet activation. Platelet stimulation causes the affinity of integrin receptors for their ligands to be upregulated and induces platelet degranulation. Secreted products from activated platelets act to recruit further platelets into the growing aggregate, as well as having strong inflammatory effects on the endothelium 
(Frenette et al. 1995). Thus, platelet interactions with the endothelium, is the major contributor to pathological thrombus formation (Ruggeri 1997).

\section{MEDITERRANEAN DIET}

The Mediterranean Diet (MD) is a complete and balanced combination of foods rich in antioxidants, which protect against CVD (Tapsell 2014). Plantbased foods are crucial on the MD, since they are rich in polyphenols (Bonaccio et al. 2012). Fruit and vegetable beverages and purees retain many beneficial components, such as flavonoids, carotenoids, vitamin $\mathrm{C}$ and dietary fibers. The PREDIMED (Prevention with MD) study is a randomized clinical trial designed to evaluate the beneficial effects of MD as primary prevention of CVD in high cardiovascular risk elderly patients (Ros et al. 2014). The MD decreases adhesion molecules in $\mathrm{T}$ - lymphocytes and monocytes, CRP and IL -6 . When including extra virgin olive oil or nuts, MD can double its effect in the prevention of CVD, decreasing typical RFCVD and triggering an intense anti-inflammatory effect, by regulating the reduction of inflammatory markers related to atherosclerosis, such as VCAM-1, ICAM 1, Pselectin Ey, CRP and IL-6 (Domenech et al. 2014, Martinez-Gonzalez et al. 2014b).

\section{NATURAL BIOACTIVE COMPOUNDS FROM FRUIT AND VEGETABLES WITH ENDOTHELIAL PROTECTION ACTIVITY}

Bioactive compounds in food provide health benefits beyond the nutritional aspects. They are usually found in small amounts in products of vegetable origin and are rich in lipids. The natural antioxidants are generally classified as phenolic compounds such as flavonoids and phenolic acids, vitamins, and volatile compounds found in various fruits, plants, herbs and spices. The active components of antioxidants derived from natural plants are polyphenolic compounds. The most effective antioxidants are those containing two or more phenolic hydroxyl groups (Ahmad et al. 2013). In figure 1, we show the main mechanisms of endothelial protection by natural bioactive compounds.

\section{POLYPHENOLS}

Epidemiological evidence suggests that polyphenols may, in part, explain the cardioprotective properties of fruit. Thus polyphenols have been shown to modulate a variety of targets in the prevention of cardiovascular diseases, which include platelet function, blood pressure, vascular function and blood lipids (Zern and Fernandez 2005, Leifert and Abeywardena 2008).

Pomegranates, red grapes and berries are fruits with relatively high concentrations of flavonols, anthocyanins and procyanidins; therefore they are effective in reducing RFCVD. Fruits rich in flavonons like oranges and grapefruit, have hypocholesterolemic effects (Chong et al. 2010). Furthermore, these compounds have a direct effect on endothelial cells. Polyphenols, grapes and berries can increase endothelial cells; powerful vasoprotectors including NO synthesis factors and endothelium-derived hyperpolarizing factor (Schini-Kerth et al. 2011).

\section{Flavonoids}

Flavonoids are a large family of over 5,000 hydroxylated polyphenolic compounds (Falcone Ferreyra et al. 2012). The dietary flavonoids are one of the main compounds that influence CVD, achieving this function by protecting the bioactivity of NO derived from endothelium. The final effect of flavonoids on NO levels will depend on the structure and concentrations of flavonoids used, in studied cell type, and especially in the presence of inflammatory/oxidative conditions (Duarte et al. 2014). Endothelial function varies widely according to the usual dietary intake and it has been shown that if flavonoids are consumed regularly in the diet by 


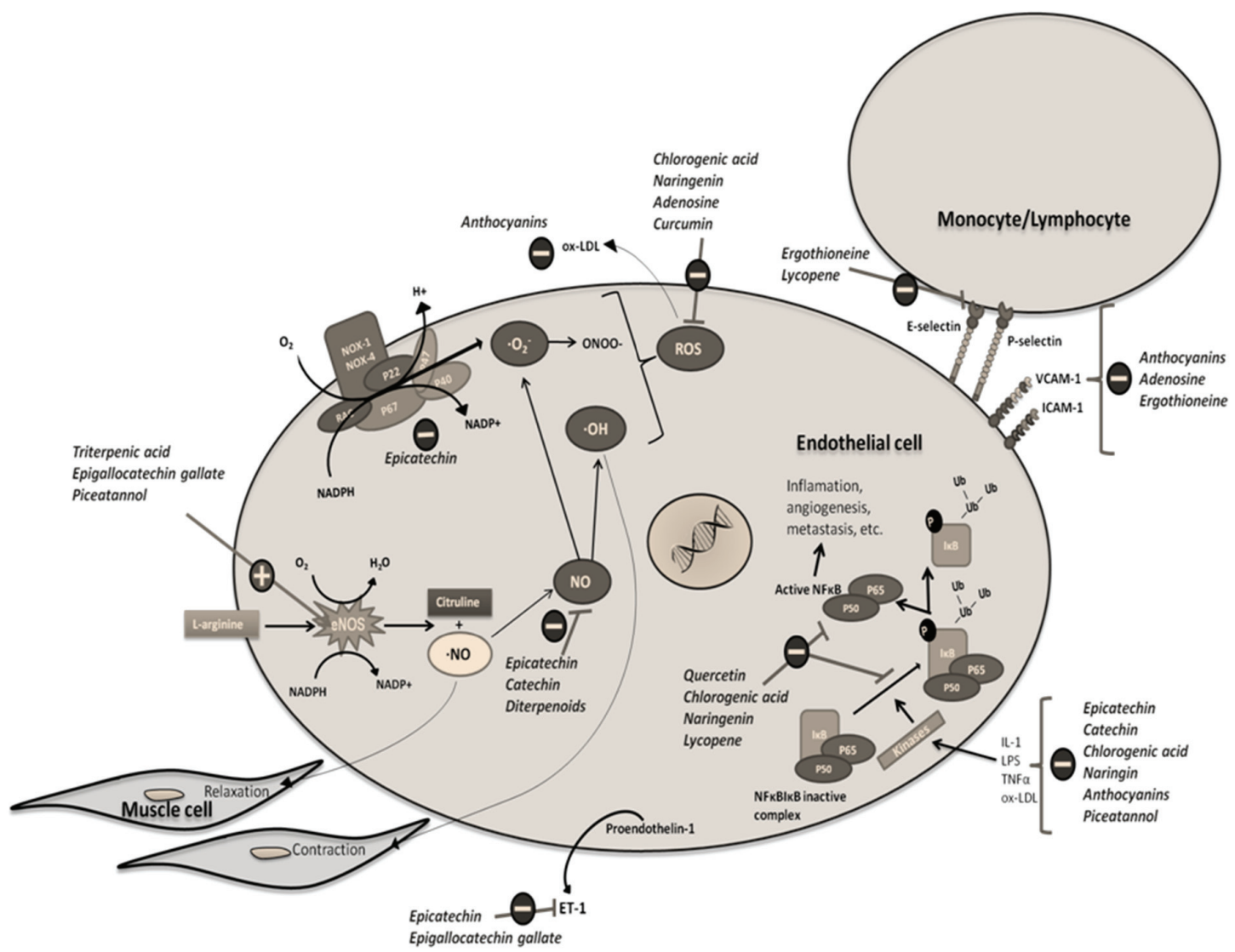

Figure 1 - The main mechanisms of endothelial protection by natural bioactive compounds. Anthocyanins, Adenosine and Ergothioneine inhibit adhesion molecules VCAM-1, ICAM-1, E-selectin, P-selectin. Lycopene and Ergothioneine inhibit leukocyte adhesion to endothelium. Epicatechin, Catechin, Chlorogenic acid, Naringin, Anthocyanins and Piceatannol inhibit proinflammatory molecules. Quercetin, Chlorogenic acid, Naringenin and Lycopene inhibit NFkB signaling pathways and preventing inflammation, angiogenesis, metastases, etc. Epicatechin, Catechin and Diterpenoids lower levels of nitric (NO) bioavailability and inhibit rust. Chlorogenic acid, Naringenin, Adenosine and Curcumin decrease reactive oxygen species (ROS). Anthocyanins decreases levels of oxidized LDL (ox-LDL). Epicatechin inhibit NADPH oxidase. Triterpenic acid, Epigallocatechin gallate and Piceatannol activate endothelial nitric oxide synthase (eNOS). Epicatechin and Epigallocatechin gallate reduce endothelin-1 (ET-1).

eating fruit and/or vegetables, endothelial function is significantly enhanced, forming part of a basal endothelial function by its action on the NO (Fisher et al. 2012). Fruit and vegetables that are rich in flavonoids improve vascular health; reduce endothelial dysfunction, inflammation and oxidative stress (Macready et al. 2014).

\section{Epicatechin}

Epicatechin is a polyphenolic flavonoid that has been isolated from a variety of natural sources (Bonilla et al. 1999). Cocoa flavonoids (Theobroma cacao L.) reduce blood pressure, improve endothelial function and increase the capacity of regeneration of the endothelium. Moreover, they also reduce levels of endothelial micro particles improving endothelial integrity (Horn et al. 2014).

Epicatechin is an important bioactive compound of cocoa and improves the endothelial function by stimulating the synthesis of NO (Jimenez et al. 2012), prevents arterial hypertension, proteinuria and endothelial dysfunction. Reduces the ET-1, vascular and systemic oxidative stress and inhibits NADPH oxidase activity (Gomez-Guzman et al. 2012). This compound also reduces synthesis bioavailability of NO and when conjugated with 
dextran, epicatechin has the ability to stimulate cellular response, therefore supporting the existence of a possible epicatechin cell membrane receptor by activating the endothelial NO synthase (eNOS) (Moreno-Ulloa et al. 2014). Studies have shown that cocoa improves vasodilation and reduces arterial stiffness in women, and its consumption decreases the endothelial dysfunction in the mesenteric arterioles induced by a high fat diet in mice (Osakabe and Shibata 2012, West et al. 2014, Grassi et al. 2005).

Flavonoids and nitrates from a diet including fruit and vegetables may have a protective cardiovascular effect and cognitive impairment through effects on NO (Bondonno et al. 2014). Reduction on CVD development risk has been associated with the consumption of apples (Pyrus malus L.), due to the effect of the main hipocolesterolemic bioactive compounds, which are fiber and polyphenols catechin, epicatechin, procyanidin $\mathrm{B} 1$ and $\beta$-carotene are the main phytocompounds responsible for the decrease in cholesterol (Serra et al. 2012). The green apple is rich in polyphenols and its epicatechin content increases NO bioavailability (Hollands et al. 2013). Consumption of apples or its bioactive compounds help modulate lipid metabolism and reduce production of proinflammatory molecules (Chai et al. 2012).

\section{Catechin}

Catechin is a polyphenolic flavonoid (Nagao et al. 2005). Both pomegranate (Punica granatum) juice and peel of are rich in polyphenols (tannins and flavonoids) that have antioxidant, anti-inflammatory and anti-cancer potential (Kelishadi et al. 2011). Pomegranate antioxidant potential comes from a specific type of tannins, the ellagitannins (punicalagin and punicalin). Various kinds of pomegranate flavonoids include anthocyanins, which give color to the fruit juice. Juice and the pomegranate peel have catechins with high antioxidant activity. Pomegranate flavonoids show antioxidant activity with the indirect inhibition of inflammatory markers, such as TNF- $\alpha$. Pomegranate juice can reduce macrophage oxidative stress, free radicals, lipid peroxidation, and also prevents cell growth and induces apoptosis. The ellagitannins also inhibit the activation of inflammatory pathways such as MAPK. Furthermore, they could inhibit angiogenesis through down regulation of vascular endothelial growth factor in cancers, thus significantly decreasing levels of reactive oxygen species (ROS). Ellagitannins and ellagic acid are metabolized by the intestinal micro flora to produce urolithins, which have anti-inflammatory properties. Since pomegranate extract is rich in polyphenols (oleanolic, ursolic and gallic acid) it could prevent cardiovascular problems by decreasing low density lipoproteins (LDL), increasing high density lipoproteins (HDL), stability and serum paraoxonase activity 1 and NO production increase (Aviram and Rosenblat 2013, Zarfeshany et al. 2014). Pomegranate juice is rich in bioactive phytochemicals with antioxidant activity and anti-inflammatory and cardioprotective functions (Asgary et al. 2013, Wu et al. 2015).

The pistachio (Pistacia vera) contains greater amount of polyphenols in the peel, such as gallic acid, catechin, cyanidin-3-O-galactoside, eriodictiol-7-O-glucoside and epicatechin, which gives it an antioxidant effect (Tomaino et al. 2010). Moreover, it significantly reduces the total peripheral resistance, the increase of cardiac output, and also improves some measures of heart rate variability. It also reduces the systolic blood pressure (BP) during sleep. A moderate-fat diet containing pistachios improves some RFCVD in well-controlled type 2 diabetes adults (Sauder et al. 2014). The pistachio has also shown improved glucose levels in blood, endothelial function, and some indices of inflammation and oxidative state in healthy young men. Moreover, decrease of 
glucose, LDL, total cholesterol and triglycerides was significant. It also improved endotheliumdependent vasodilation, decreased serum IL6 , total oxidant state, and lipid hydroperoxide and malondialdehyde, and increased superoxide dismutase (Sari et al. 2010). Thus pistachio and gallic acid as its main constituents decrease inflammatory biomarkers as well as inhibit lipid accumulation (Grace et al. 2015). Gallic acid is well known for its antioxidant and hepatoprotective activity, but its effectiveness is limited due to its rapid metabolism and elimination, so there have been created methods to increase its bioavailability with the formation of phospholipid complexes improving its absorption in rats (Bhattacharyya et al. 2013).

Polyphenols in red wine induce NO synthesis and the endothelium derived hyperpolarization mediated though coronary vasodilation, which includes dependent PI3-kinase / Akt redox-sensitive pathway in the endothelium. The flavonoids act on the endothelium through the bilitranslocase, which is a membrane flavonoids transporter (Ziberna et al. 2013). Another study showed that red wine also contains polyphenols such as epicatechin and catechin, showing that the latter appears to be an antiatherogenic compound more effective than epicatecuin in hyperhomocysteinemia and should be considered as a new therapeutic approach against induced endothelial dysfunction by this condition (Noll et al. 2013).

\section{Anthocyanidins}

Anthocyanins are members of the flavonoid group of phytochemicals, which is a group predominant in tea, honey, wine, fruit, vegetables, nuts, olive oil, cocoa and cereals. Anthocyanins are water-soluble phytochemicals with a typical red to blue color (Lila 2004, Woodward et al. 2009). Recently, oriental persimmon (Diospyros kaki Thunb. Cv. Fuyu) extract has been studied for its antiatherogenic properties (Son et al. 2013). This fruit contains bioactive molecules that can improve endothelial function through activation of eNOS and reduced secretion of ET-1 (Woodcock et al. 2013). These polyphenols also exhibit an antihypertensive effect of proanthocyanidins due to vascular relaxation via endothelium dependent NO/cGMP pathway, and may be useful in reducing BP (Kawakami et al. 2011).

\section{Epigallocatechin gallate}

Epigallocatechin gallate is the ester of epigallocatechin and gallic acid, and is a type of catechin $(\mathrm{Du}$ et al. 2012). Green tea has several functional effects, such as anti-inflammatory and antioxidant activities (Matsumoto et al.2013). Epigallocatechin-3-gallate (EGCG) in the most abundant polyphenol in green tea and has vasodilatory effect by activating eNOS. EGCG may have beneficial health effects on glucose metabolism and endothelial function through the modulation of the inflammatory response induced by a high fat diet (Kim et al. 2013a). By improving endothelial function, EGCG decreases the progression of atherosclerosis (Minatti et al. 2012). EGCG has therapeutic potential for endotoxin mediated endothelial inflammation (Li et al. 2012). Moreover, EGCG regulates the accumulation of ectopic fat through autophagy flow making it in a potential therapeutic reagent to prevent cardiovascular complications (Kim et al. 2013a). Unfortunately it exhibits low bioavailability due to bad intestinal transport, metabolism and rapid clearance (Peters et al. 2010).

\section{Quercetin}

Quercetin is a polyphenol present in fruit and vegetables that also contributes to cardiovascular health (Arai et al. 2000). It protects against endothelial dysfunction, induced by oxidants, and against atherosclerosis. These effects are associated with increased NO bioavailability and are related with HO-1 blood induction (Shen et al. 2013). Onion (Allium cepa) is rich in quercetin. In some in vitro studies, quercetin improved endothelial 
function associated with atherosclerosis, which is a cause of CVD (Nakayama et al. 2013). Furthermore, it prevents diabetic vascular complications, both in insulin deficiency and resistance through its inhibitory effect on inflammatory pathways especially NF-kB signaling (Mahmoud et al. 2013).

\section{Chlorogenic acid}

Coffee is one of the most widely consumed beverages, both in the United States and worldwide. Three large prospective cohort studies demonstrated that higher consumptions of total coffee, caffeinated coffee, and decaffeinated coffee were associated with lower risk of total mortality (Ding et al. 2015). With respect to the association between coffee consumption and cardiovascular mortality, moderate coffee consumption was inversely significantly associated with CVD, with the lowest CVD risk at 3 to 5 cups/day, and heavy coffee consumption was not associated with elevated CVD risk (Ding et al. 2014, Loomba et al. 2014, Zhang et al. 2009). This is controversial, since other recently published studies show the opposite (Liu et al. 2013, Sugiyama et al. 2010). The heterogeneous findings may be due to differences between casecontrol and prospective study designs and possibly also to inconsistent control for important confounders such as tobacco smoking. In addition, the numbers of deaths have been small in most studies (Freedman et al. 2012). Therefore, coffee consumption at any dosage appears to be safe and does not represent an increase in mortality risk (Loomba et al. 2014).

The main polyphenol present in coffee is chlorogenic acid (CGA), which has shown to improve endothelial function in mice fed a high-fat diet (Li Kwok Cheong et al. 2014). CGA reduces BP acutely and does not affect endothelial function or NO states (Mubarak et al. 2012). CGA inhibits adhesion of monocytes, production of ROS, translocation of NFkB and expression of adhesion molecules (Chang et al. 2010). CGA present in coffee is well absorbed and metabolized by humans (Farah et al. 2008).

Polyphenols in lemon grass (Cymbopogon citratus) have antioxidant, anti-inflammatory and chemopreventive properties (Rahim et al. 2013). Phytochemically they include tannins, flavonoids, terpenoids and methanol extracts as alkaloids and steroids (Soares et al. 2013). This protects the human umbilical vein endothelial cells (HUVEC) from oxidative damage induced hyperglycemia, hydrogen peroxide and LDL-ox. Its antioxidant properties can prevent endothelial dysfunction associated with oxidative imbalance caused by different oxidative stimuli (Campos et al. 2014). Anti-inflammatory activity is due to its chlorogenic acid content, through proteasome inhibition and consequently NFkB pathway and expression of cytokines in human macrophages (Francisco et al. 2013).

\section{Anthocyanins}

The anthocyanins are the main group of natural water soluble plant pigments (Tanaka et al. 2008). They have beneficial effects in preventing CVD and neurological diseases. They show antihypertensive, endothelium-protective and antiatherogenic activity, as well as interaction with the estrogen receptor. Different anthocyanin structures not only have an impact on their colors, but also affect their interaction with the different steps of the main pathways related to these diseases. Therefore, different colors can show different molecular mechanisms (de Pascual-Teresa 2014). Moreover, anthocyanins are a group of flavonoids that have anti-inflammatory and antioxidant properties. They showed an increase in HDL cholesterol levels in prehypertensives men without dyslipidemia (Hassellund et al. 2013).

Proanthocyanins are found in grape seeds in abundance. They have antithrombotic properties that are associated with endothelial protection 
and inhibition of inflammatory cells adhesion, because it causes a decrease in the expression of P-selectin thus inhibiting leukocytes recruitment and thrombosis (Zhang et al. 2011).

Blueberries (Vaccinium corymbosum L.) are a rich source of anthocyanins, which protect cells against oxidative stress, reduce BP and improve endothelial dysfunction induced by high cholesterol $\operatorname{diet}$ (Del Bo et al. 2013). Wild blueberries are rich in flavonoids, phenolic acids and anthocyanins, which protect them from oxidation. Cranberries contain polyphenols that improve endothelial function, reduce RFCVD, lipid oxidation, inflammation and dyslipidemia in patients with metabolic syndrome. Moreover, they reduce the levels of total cholesterol and triglycerides; improve endothelium -dependent relaxation in the aorta of ovariectomized rats restoring P-eNOS, changes in regulated levels up to marker of renin-angiotensin system and normalize the expression of NADPH oxidase and oxidative stress (Flammer et al. 2013).

Strawberries (Fragaria vesca) have antioxidant activity and reduce RFCVD, such as high BP, hyperglycemia, dyslipidemia and inflammation (Basuetal.2010). Strawberries containanthocyanins that improve plasma lipid profile; biomarkers of antioxidant state and modulate platelet function in healthy subjects (Alvarez-Suarez et al. 2014). Furthermore, they trigger antithrombotic effects in mice, inhibit platelet aggregation, reduce the P-selectin expression and decrease sCD40L serum, RANTES and IL- 1 $\beta$ (Alarcon et al. 2014). Although strawberry phenolic compounds are known mainly for their anti-inflammatory actions and antioxidant properties, recent studies have shown that their biological activities were also extended to other pathways involved in metabolism and cell survival (Giampieri et al. 2014, Manach et al. 2005).

Nuts are rich in many bioactive compounds, especially anthocyanins that may have beneficial effects on cardiovascular health. Hazelnuts (Corylus avellana), for example, contain 6.71 mg of anthocyanins per 100 grams (Kozlowska and Szostak-Wegierek 2014) and decrease inflammation and endothelial dysfunction markers (Tey et al. 2013). Meanwhile, nuts (Junglas regia) have a protective effect on endothelial function and AP (Salas-Salvado et al. 2014). Consuming a diet enriched with hazelnuts significantly improves flow-mediated dilation, levels of total cholesterol, tryglicerides, LDL, HDL, reduces LDL-ox, hsCRP and sVCAM-1. Moreover, they present an antiatherogenic effect by improving endothelial function, prevention of LDL, inflammatory markers and lipid oxidation in addition to lowering lipoproteins (Orem et al. 2013, Tey et al. 2011). Furthermore hazelnut consumption can prevent reduction of HDL (Azadbakht and Rouhani 2013). Hazelnuts can be incorporated into the daily diet, causing no change in a healthy total caloric intake (Orem et al. 2013).

Malvidin is an anthocyanin found in the skin of red grapes that has cardioprotective effects (Quintieri et al. 2013). Malvidin decreases the regulation of NO generation and inhibits the synthesis of TNF, IL-1 and IL-6; making it a powerful anti-inflammatory flavonoid without toxic effect (Huang et al. 2016).

\section{Delphinidin}

Delphinidin is an anthocyanidin, a primary plant pigment, and also an antioxidant (Lamy et al. 2006). Maqui (Aristotelia chilensis) is a Chilean species that has health benefits for its high content of anthocyanins (Fredes et al. 2014). It is a good source delphinidins, an anthocyanin that has potent antioxidant activity, as it reduces the oxidative stress (oxLDL) and glucose in blood, increases eNOS expression, decreases the expression of endothelin - 1 vasoconstriction and cell molecules adhesion ICAM 1 and VCAM-1. Furthermore, it decreases platelet activity preventing thrombosis (Watson and Schonlau 2015). 


\section{Resveratrol}

Resveratrol is a stilbenoid, a type of natural phenol. A high intake of polyphenols, especially of stilbenes and lignans, reduces the risk of overall mortality when compared with individuals with lower intake (Yurdagul et al. 2014). Resveratrol is a stilbene that promotes re-endothelialization after arterial injury and improves wound healing (Yurdagul et al. 2014, Troped et al. 2010). Resveratrol (trans-3, 5,4 '- trihydroxystilbene) is a phytoalexin found in foods such as grapes, plums, blueberries and peanuts (Atmaca et al. 2014). Its antioxidant efficacy has been demonstrated in traumatic brain injury, methotrexate-induced hepatic toxicity, gentamicin-induced nephrotoxicity, and doxorubicin induced cardiotoxicity (Dalaklioglu et al. 2013, Tunali-Akbay et al. 2010). Resveratrol attenuates endothelial inflammation by inducing autophagy (cellular process that protects cells from stressful conditions), which is mediated through the activation of the signaling cAMP-PRKA-AMPKSIRT1 pathway (Chen et al. 2013). Resveratrol has low systemic bioavailability, but despite this, their accumulation in the endothelial cells may have a preventive effect of cancer, among others (Walle et al. 2004).

\section{Naringenin}

Naringenin is a flavanone compound found in citrus fruit such as oranges (Citrus sinensis) and grapes (Vitis vinifera). It regulates oxidative stress decreasing levels of ROS and regulates the MAPK / NF - кB pathway (Xu et al. 2013). It has been found that the main flavonoid in orange juice is hesperidin that decreases diastolic BP when consumed regularly (Morand et al. 2011).

\section{Naringin}

Naringin is a flavanone-7-O-glycoside between the flavanone Naringenin and the disaccharide neohesperidose. Grapefruit (Citrus $x$ paradisi) has a high content of antioxidants and anti-inflammatory substances. Naringin, which is responsible for the sour taste of grapefruit, decreases inflammatory cells infiltration, oxidative stress and reduces plasma lipid concentration, and also improves mitochondrial liver function in mice (Alam et al. 2013). A study in diabetics with increased cardiovascular risk found that endothelial function, which is measured as flow mediated dilation, improves significantly and normalizes after a week of grapefruit juice consumption (Buscemi et al. 2012).

\section{Piceatannol and scirpusin B}

The piceatannol and scirpusin B are polyphenolic compounds that are present in high quantities in passion fruit (Passiflora edulis) seeds. Both compounds have antioxidant activity and vasodilator effect. The latter effect is explained by the increase of NO, which reduces the CVD risk (Sano et al. 2011). There have also been similar studies with passion fruit skin that also showed positive results as a potential source of antioxidant (Wong et al. 2014, Zeraik et al. 2011). Studies show that passion fruit has another bioactive compound named pectin, which significantly reduces neutrophil infiltration and partially decreases TNF- $\alpha$ (Silva et al. 2011, Yapo and Koffi 2006).

\section{Tyrosol and hydroxytyrosol}

Tyrosol and hydroxytyrosol are absorbed from moderate and sustained doses of virgin olive oil in humans (Miró-Casas et al. 2003). Consumption of extra virgin olive oil is associated with lower CVD risk and mortality in people with high cardiovascular risk (Guasch-Ferre et al. 2014). Eating a diet rich in polyphenols containing olive oil can decrease the BP and improve endothelial function (MorenoLuna et al. 2012). The main phenolic in olive oil are tyrosol and hydroxytyrosol, however it also contains flavones apigenin and luteolin (Tagliaferri et al. 2014). Hydroxytyrosol helps to reduce plasma lipid levels and repair oxidative damage associated 
with CVD (de la Torre-Robles et al. 2014, MiróCasas et al. 2001). Moreover, olive oil pomace concentrates triterpene acids, which attenuates the increase in BP, improving dependent endothelium relaxation, increased vascular expression of eNOS, and reduction of TNF alpha and transforming growth beta factor (Valero-Munoz et al. 2014). Its consumption is inversely associated with stroke and coronary heart disease (Martinez-Gonzalez et al. 2014a).

\section{CAROTENOIDS}

\section{Crocetin}

Crocetin is a natural dicarboxylic acid carotenoid found in the crocus flower (Crocus sativus) and fruits of gardenia (Gardenia jasminoides). It is used worldwide as an important spice, food coloring and herbal medicine (Higashino et al. 2014). Crocetin effects were studied on induced angiogenesis, vascular endothelial growth factor (VEGF), in in vitro tube formation assays and after 14 days of co-culture of HUVEC and fibroblasts. Angiogenesis suppression has been demonstrated that is induced by VEGF through inhibiting migration and expression of p38 - phosphorylated and VE- cadherin protection (Umigai et al. 2012). Antihypertensive and antithrombotic effects of crocetin relate to an increased NO bioavailability, possibly mediated by decreased NO inactivation through ROS (Higashino et al. 2014).

\section{Lycopene}

Lycopene is a carotenoid principally responsible for the characteristic deep-red color of ripe tomato fruits and tomato products (Shi and Le Maguer 2000). Tomato (Solanum lycopersicum) is an herbaceous plant that contains several phytochemicals, such as vitamin C, potassium, folate and carotenoids like lycopene, among others. Carotenoids are pigments synthesized during fruit ripening and lycopene in particular is responsible for the red color of tomatoes (Perveen et al. 2013). Consumption of tomato paste improves endothelial function (Xaplanteris et al. 2012). Lycopene is hypolipidemic and inhibits pro-thrombotic and pro-inflammatory factors (Mordente et al. 2011, Bohn et al. 2013). Consumption of tomato products attenuates postprandial oxidative stress induced by lipemia and associated inflammatory response, demonstrating a protective role of tomato by reducing CVD risk (Burton-Freeman et al. 2012). Tomato oleoresin interferes inflammatory signaling in endothelial cells, imitating the inflammatory processes reduction in the vessel wall and reducing BP. Prevention of adhesion molecules overexpression through inhibition of NF-kB signaling is one of the main mechanisms of carotenoids to reduce leukocyte adhesion to endothelium (Armoza et al. 2013).

\section{NUCLEOSIDES}

Nucleosides are glycosylamines that can be thought of as nucleotides without a phosphate group. Adenosine is an abundant active ingredient in the extract of black soybean is also associated with antiplatelet activity (Kim et al. 2013b). One study showed that supplemental intake of soy isoflavones for 6 and 12 months had an effect on oxidative stress by decreasing the concentration of malondialdehyde (MDA) (Pusparini et al. 2013). Soy protein reduces lipid and BP, reducing levels of E-selectin and leptin (Rebholz et al. 2013). Fermented soy extracts inhibit ROS production (Lim et al. 2012). Soy isoflavones can be divided into three chemical groups: daidzein, genistein and glycitin, which vary in their bioavailability (Chang and Choue 2013).

\section{UNSATURATED FATTY ACIDS}

Unsaturated fatty acids have one or more double bonds between carbon atoms. Walnuts improve endothelial function in overweight adults and 
visceral adiposity; also they do not increase weight and can prevent CVD (Katz et al. 2012). Studies have shown that consumption of nuts increased the concentration of HDL, and decreased total cholesterol and LDL-C compared with a control diet (Banel and $\mathrm{Hu}$ 2009, Cominetti et al. 2012, Ros et al. 2004). Walnuts are a rich source of $\alpha$-linoleic acid (ALA) ( 13\% of total lipids) and $\gamma$-tocopherol $(20 \mathrm{mg} / 100 \mathrm{~g})$ and contain phytosterols $(164 \mathrm{mg} / 100 \mathrm{~g})$. Walnut oil promotes endothelial function, partly due to ALA and/or increased bioavailability. Decreases the antioxidant potential reduction of iron (FRAP), and whole nuts increase the efflux of cholesterol (Berryman et al. 2013). A study showed that daily consumption of 43 grams of nuts per 8 weeks significantly reduced non-HDL cholesterol and Apo B, decreasing the risk of coronary heart disease (Wu et al. 2014).

\section{TERPENOIDS}

Curcuminoids and terpenoids are typical bioactive compounds from turmeric (Curcuma longa L.) (Lee et al. 2014). Curcumin is recognized for their antioxidant properties, thus it significantly decreases endothelial dysfunction induced by diabetes through lowering superoxide inhibition and PKC inhibition (Rungseesantivanon et al. 2010). Also inhibits LDL-ox from receptor-1 (LOX-1) and suppresses the inflammatory response in HUVEC by antioxidants processes (Lee et al. 2010). Studies suggest that the immunomodulatory effects of curcumin occur because of IL- $1 \beta$, IL - 4 and VEGF serum modification (Ganjali et al. 2014, Gao et al. 2004, Varalakshmi et al. 2008). Curcumin has low bioavailability because it is poorly absorbed in the gut and undergoes rapid metabolism in the liver (Tsai et al. 2012).

Sesquiterpenoids and Siegesbeckia pubescens diterpenoids isolated inhibit NO production in macrophages. Active terpenoids present in Siegesbeckia could be used as anti-inflammatory agents (Wang et al. 2014). The ent-16ß,17- dihydroxy-kauran-19-oic acid (DDKA) has antiplatelet and antithrombotic activity. Both effects were studied from isolated DDKA $S$. pubescens. DDKA prolonged prothrombin time and partial thromboplastin time in rats after intravenous administration during 5 successive days. DDKA has antiplatelet activity in rats and causes an increase in intraplatelet cAMP levels (Wang et al. 2011).

\section{OTHERS}

\section{Nitrates}

Nitrate is a polyatomic ion with the molecular formula $\mathrm{NO}_{3}$. Presence of nitrates from beet (Beta vulgaris) in the diet, reduce BP by sequential reduction of nitrate to nitrite and then to $\mathrm{NO}$ in the circulation (Hobbs et al. 2013). Beetroot, which is rich in inorganic nitrates, reduces the deterioration of endothelial function associated with the ingestion of a mixed meal (Joris and Mensink 2013). Moreover, it improves endothelial function, increases nitrite in plasma and improves insulin sensitivity in people with type 2 diabetes (Gilchrist et al. 2013).

Flavonoids and nitrates in the diet can increase the NO through different pathways, which can improve the endothelial function and the BP. Recent studies suggest that the combination of flavonoids and nitrates can enhance NO production in the stomach (Bondonno et al. 2012, Peri et al. 2005). Furthermore, it was shown that diets high in nitrates rich apples flavonoids and spinach (Spinacia oleracea) may increase independently NO levels, improve the endothelial function and reduce BP acutely, all of which can benefit cardiovascular health (Bondonno et al. 2012).

\section{Ergothioneine}

Ergothioneine (ET) is a bioactive antioxidant compound present in edible fungi that, although it is not synthesized can be accumulated by humans through diet. ET interrupts proinflammatory induction of adhesion molecules expression 
associated with atherogenesis, thus reducing the risk CVD. ET reduces VCAM -1, ICAM-1 and E-selectin (Martin 2010). ET is absorbed by the endothelial cells through type 1 (OCTN-1) organic cation transporter and protects against oxidative stress, therefore reducing the endothelial dysfunction (Li et al. 2014).

\section{CONCLUSIONS}

It was demonstrated in this article that high intakes of fruit and vegetables are associated with a decrease in cardiovascular diseases via endothelial protection. Thus the most important fruit/vegetables and bioactive compounds to prevent endothelial diseases are berries, apples, virgin olive oil, tomatoes, soybeans, and polyphenols, carotenoids and unsaturated fatty acids, respectively. The bioactive compounds from fruit and vegetables provide endothelial protection through the following mechanisms: improved eNOS/NO bioavailability, attenuates oxidative stress, inhibited NF- $\kappa \mathrm{B}$ pathway and decreased cell adhesion molecules expression. In table SI (Supplementary Material) we show endothelial cell protection by natural bioactive compounds from fruit and vegetables.

\section{ACKNOWLEDGMENTS}

Eduardo Fuentes thanks Fondo Nacional de Desarrollo Científico y Tecnológico (FONDECYT) $\mathrm{N}^{\circ}$ 11140142. This work was also funded by Interdisciplinary Excellence Research Program on Healthy Aging (PIEI-ES).

\section{REFERENCES}

AHMAD SR, GOKULAKRISHNAN P, GIRIPRASAD R AND YATOO MA. 2013. Fruit Based Natural Antioxidants in Meat and Meat Products: A Review. Crit Rev Food Sci 55: 1503-1513.

AIRD WC. 2007. Phenotypic heterogeneity of the endothelium: I. Structure, function, and mechanisms. Circ Res 100: 158-173.

ALAM MA, KAUTER K AND BROWN L. 2013. Naringin improves diet-induced cardiovascular dysfunction and obesity in high carbohydrate, high fat diet-fed rats. Nutrients 5: 637-650.
ALARCON M, FUENTES E, OLATE N, NAVARRETE S, CARRASCO G AND PALOMO I. 2014. Strawberry extract presents antiplatelet activity by inhibition of inflammatory mediator of atherosclerosis (sP-selectin, sCD40L, RANTES, and IL-1beta) and thrombus formation. Platelets 26: 224-229.

ALVAREZ-SUAREZ JM ET AL. 2014. One-month strawberry-rich anthocyanin supplementation ameliorates cardiovascular risk, oxidative stress markers and platelet activation in humans. J Nutr Biochem 25: 289-294.

ARAI Y, WATANABE S, KIMIRA M, SHIMOI K, MOCHIZUKI R AND KINAE N. 2000. Dietary intakes of flavonols, flavones and isoflavones by Japanese women and the inverse correlation between quercetin intake and plasma LDL cholesterol concentration. J Nutr 130: 2243-2250.

ARMOZAA, HAIM Y, BASHIRI A, WOLAK T AND PARAN E. 2013. Tomato extract and the carotenoids lycopene and lutein improve endothelial function and attenuate inflammatory NF-kappaB signaling in endothelial cells. J Hypertens 31: 521-529; discussion 529.

ASGARY S, KESHVARI M, SAHEBKAR A, HASHEMI M AND RAFIEIAN-KOPAEI M. 2013. Clinical investigation of the acute effects of pomegranate juice on blood pressure and endothelial function in hypertensive individuals. ARYA Atheroscler 9: 326-331.

ATMACA N, YILDIRIM E, GUNER B, KABAKCI R AND BILMEN FS. 2014. Effect of resveratrol on hematological and biochemical alterations in rats exposed to fluoride. BioMed Research International 2014: 698628.

AVIRAM M AND ROSENBLAT M. 2013. Pomegranate for your cardiovascular health. Rambam Maimonides Med J 4: e0013.

AZADBAKHT L AND ROUHANI MH. 2013. Nuts consumption and cardiovascular risks. J Res Med Sci: The Official Journal of Isfahan University of Medical Sciences 18: 272-273.

BANEL DK AND HU FB. 2009. Effects of walnut consumption on blood lipids and other cardiovascular risk factors: a meta-analysis and systematic review. Am J Clin Nutr 90: 56-63.

BASU A, FU DX, WILKINSON M, SIMMONS B, WU M, BETTS NM, DU M AND LYONS TJ. 2010. Strawberries decrease atherosclerotic markers in subjects with metabolic syndrome. Nutr Res 30: 462-469.

BAUTISTA LE, OROSTEGUI M, VERA LM, PRADA GE, OROZCO LC AND HERRAN OF. 2006. Prevalence and impact of cardiovascular risk factors in Bucaramanga, Colombia: results from the Countrywide Integrated Noncommunicable Disease Intervention Programme (CINDI/CARMEN) baseline survey. Eur J Cardiovasc Prev Rehabil 13: 769-775.

BERRYMAN CE， GRIEGER JA，WEST SG, CHEN CY, BLUMBERG JB, ROTHBLAT GH, SANKARANARAYANAN S AND KRIS-ETHERTON 
PM. 2013. Acute consumption of walnuts and walnut components differentially affect postprandial lipemia, endothelial function, oxidative stress, and cholesterol efflux in humans with mild hypercholesterolemia. J Nutr 143: 788-794.

BHATTACHARYYA S, AHAMMED SM, SAHA BP AND MUKHERJEE PK. 2013. The gallic acid-phospholipid complex improved the antioxidant potential of gallic acid by enhancing its bioavailability. AAPS PharmSciTech 14: 1025-1033.

BOHN T, BLACKWOOD M, FRANCIS D, TIAN Q, SCHWARTZ SJAND CLINTON SK. 2013. Bioavailability of phytochemical constituents from a novel soy fortified lycopene rich tomato juice developed for targeted cancer prevention trials. Nutr Cancer 65: 919-929.

BONACCIO M, IACOVIELLO L, DE GAETANO G AND MOLI-SANI I. 2012. The Mediterranean diet: the reasons for a success. Thromb Res 129: 401-404.

BONDONNO CP ET AL. 2014. The acute effect of flavonoidrich apples and nitrate-rich spinach on cognitive performance and mood in healthy men and women. Food Funct 5: 849-858.

BONDONNO CP, YANG X, CROFT KD, CONSIDINE MJ, WARD NC, RICH L, PUDDEY IB, SWINNY E, MUBARAK A AND HODGSON JM. 2012. Flavonoidrich apples and nitrate-rich spinach augment nitric oxide status and improve endothelial function in healthy men and women: a randomized controlled trial. Free Radical Bio Med 52: 95-102.

BONILLA F, MAYEN M, MERIDA J AND MEDINA M. 1999. Extraction of phenolic compounds from red grape marc for use as food lipid antioxidants. Food Chem 66: 209-215.

BURTON-FREEMAN B, TALBOT J, PARK E, KRISHNANKUTTY S AND EDIRISINGHE I. 2012. Protective activity of processed tomato products on postprandial oxidation and inflammation: a clinical trial in healthy weight men and women. Mol Nutr Food Res 56: 622-631.

BUSCEMI S, ROSAFIO G, ARCOLEO G, MATTINA A, CANINO B, MONTANA M, VERGA S AND RINI G. 2012. Effects of red orange juice intake on endothelial function and inflammatory markers in adult subjects with increased cardiovascular risk. Am J Clin Nutr 95: 1089-1095.

CAI H AND HARRISON DG. 2000. Endothelial dysfunction in cardiovascular diseases: the role of oxidant stress. Circ Res 87: 840-844.

CAMPOS J ET AL. 2014. Lemon grass (Cymbopogon citratus (D.C) Stapf) polyphenols protect human umbilical vein endothelial cell (HUVECs) from oxidative damage induced by high glucose, hydrogen peroxide and oxidised low-density lipoprotein. Food Chem 151: 175-181.
CASAS R ET AL. 2014. The effects of the mediterranean diet on biomarkers of vascular wall inflammation and plaque vulnerability in subjects with high risk for cardiovascular disease. A randomized trial. PloS one 9: e100084.

COMINETTI C, DE BORTOLI MC, GARRIDO JR AB AND COZZOLINO SM. 2012. Brazilian nut consumption improves selenium status and glutathione peroxidase activity and reduces atherogenic risk in obese women. Nutr Res 32: 403-407.

CHAI SC, HOOSHMAND S, SAADAT RL, PAYTON ME, BRUMMEL-SMITH K AND ARJMANDI BH. 2012. Daily apple versus dried plum: impact on cardiovascular disease risk factors in postmenopausal women. J Acad Nutr Diet 112: 1158-1168.

CHANG WC, CHEN CH, LEE MF, CHANG T AND YU YM. 2010. Chlorogenic acid attenuates adhesion molecules upregulation in IL-1beta-treated endothelial cells. Eur J Nutr 49: 267-275.

CHANG Y AND CHOUE R. 2013. Plasma pharmacokinetics and urinary excretion of isoflavones after ingestion of soy products with different aglycone/glucoside ratios in South Korean women. Nutr Res Pract 7: 393-399.

CHEN ML ET AL. 2013. Resveratrol attenuates vascular endothelial inflammation by inducing autophagy through the cAMP signaling pathway. Autophagy 9: 2033-2045.

CHONG MF, MACDONALD R AND LOVEGROVE JA. 2010. Fruit polyphenols and CVD risk: a review of human intervention studies. BR J Nutr 104(Suppl 3): S28-39.

DALAKLIOGLU S, GENC GE, AKSOY NH, AKCIT F AND GUMUSLU S. 2013. Resveratrol ameliorates methotrexate-induced hepatotoxicity in rats via inhibition of lipid peroxidation. Hum Exp Toxicol 32: 662-671.

DAUCHET L, AMOUYEL P, HERCBERG S AND DALLONGEVILLE J. 2006. Fruit and vegetable consumption and risk of coronary heart disease: a metaanalysis of cohort studies. J Nutr 136: 2588-2593.

DE LA TORRE-ROBLES A, RIVAS A, LORENZO-TOVAR ML, MONTEAGUDO C, MARISCAL-ARCAS M AND OLEA-SERRANO F. 2014. Estimation of the intake of phenol compounds from virgin olive oil of a population from southern Spain. Food addit contam Part A Chem Anal Control Expo Risk Assess 3(9): 1460-1469.

DE PASCUAL-TERESA S. 2014. Molecular mechanisms involved in the cardiovascular and neuroprotective effects of anthocyanins. Arch Biochem Biophys 559: 68-74.

DEANFIELD JE, HALCOX JP AND RABELINK TJ. 2007. Endothelial function and dysfunction: testing and clinical relevance. Circulation 115: 1285-1295.

DEL BO C, RISO P, CAMPOLO J, MOLLER P, LOFT S, KLIMIS-ZACAS D, BRAMBILLA A, RIZZOLO A AND PORRINI M. 2013. A single portion of blueberry (Vaccinium corymbosum L.) improves protection against 
DNA damage but not vascular function in healthy male volunteers. Nutr Res 33: 220-227.

DING M, BHUPATHIRAJU SN, SATIJA A, VAN DAM RM AND HU FB. 2014. Long-term coffee consumption and risk of cardiovascular disease: a systematic review and a dose-response meta-analysis of prospective cohort studies. Circulation 129: 643-659.

DING M, SATIJA A, BHUPATHIRAJU SN, HU Y, SUN Q, HAN J, LOPEZ-GARCIA E, WILLETT W, VAN DAM RM AND HU FB. 2015. Association of Coffee Consumption With Total and Cause-Specific Mortality in 3 Large Prospective Cohorts. Circulation 132: 2305-2315.

DOMENECH M ET AL. 2014. Mediterranean diet reduces 24-hour ambulatory blood pressure, blood glucose, and lipids: one-year randomized, clinical trial. Hypertension 64: 69-76.

DU GJ, ZHANG Z, WEN XD, YU C, CALWAY T, YUAN CS AND WANG CZ. 2012. Epigallocatechin Gallate (EGCG) is the most effective cancer chemopreventive polyphenol in green tea. Nutrients 4: 1679-1691.

DUARTE J, FRANCISCO V AND PEREZ-VIZCAINO F. 2014. Modulation of nitric oxide by flavonoids. Food Funct 5: 1653-1668.

ETINGIN OR, SILVERSTEIN RL AND HAJJAR DP. 1993. von Willebrand factor mediates platelet adhesion to virally infected endothelial cells. Proc Natl Acad Sci USA 90: 5153-5156.

FALCONE FERREYRA ML, RIUS SP AND CASATI P. 2012. Flavonoids: biosynthesis, biological functions, and biotechnological applications. Front Plant Sci 3: 222.

FARAH A, MONTEIRO M, DONANGELO CMAND LAFAY S. 2008. Chlorogenic acids from green coffee extract are highly bioavailable in humans. J Nutr 138: 2309-2315.

FISHER ND, HURWITZ S AND HOLLENBERG NK. 2012. Habitual flavonoid intake and endothelial function in healthy humans. J Am Coll Nutr 31: 275-279.

FLAMMER AJ, MARTIN EA, GOSSL M, WIDMER RJ, LENNON RJ, SEXTON JA, LOEFFLER D, KHOSLA S, LERMAN LO AND LERMAN A. 2013. Polyphenol-rich cranberry juice has a neutral effect on endothelial function but decreases the fraction of osteocalcin-expressing endothelial progenitor cells. Eur J Nutr 52: 289-296.

FRANCISCO V, COSTA G, FIGUEIRINHA A, MARQUES C, PEREIRA P, NEVES BM, LOPES MC, GARCÍARODRÍGUEZ C, CRUZ MT AND BATISTA MT. 2013. Anti-inflammatory activity of Cymbopogon citratus leaves infusion via proteasome and nuclear factor-kappaB pathway inhibition: contribution of chlorogenic acid. $\mathrm{J}$ Ethnopharmacol 148: 126-134.

FREDES C, YOUSEF GG, ROBERT P, GRACE MH, LILA MA, GOMEZ M, GEBAUER M AND MONTENEGRO G. 2014. Anthocyanin profiling of wild maqui berries (Aristotelia chilensis [Mol.] Stuntz) from different geographical regions in Chile. J Sci Food Agr 94: 2639-2648.
FREEDMAN ND, PARK Y, ABNET CC, HOLLENBECK AR AND SINHA R. 2012. Association of coffee drinking with total and cause-specific mortality. N Engl J Med 366: 1891-1904.

FRENETTE PS, JOHNSON RC, HYNES RO AND WAGNER DD. 1995. Platelets roll on stimulated endothelium in vivo: an interaction mediated by endothelial P-selectin. Proc Natl Acad Sci USA 92: 7450-7454.

GANJALI S, SAHEBKAR A, MAHDIPOUR E, JAMIALAHMADI K, TORABI S, AKHLAGHI S, FERNS G, PARIZADEH SM AND GHAYOUR-MOBARHAN M. 2014. Investigation of the effects of curcumin on serum cytokines in obese individuals: a randomized controlled trial. Scientific World Journal 2014: 898361.

GAO X, KUO J, JIANG H, DEEB D, LIU Y, DIVINE G, CHAPMAN RA, DULCHAVSKY SA AND GAUTAM SC. 2004. Immunomodulatory activity of curcumin: suppression of lymphocyte proliferation, development of cell-mediated cytotoxicity, and cytokine production in vitro. Biochem Pharmacol 68: 51-61.

GIAMPIERI F, ALVAREZ-SUAREZ JM AND BATTINO M. 2014. Strawberry and Human Health: Effects beyond Antioxidant Activity. J Agr Food Chem 62: 3867-3876.

GILCHRIST M, WINYARD PG, AIZAWA K, ANNING C, SHORE A AND BENJAMIN N. 2013. Effect of dietary nitrate on blood pressure, endothelial function, and insulin sensitivity in type 2 diabetes. Free Radical Bio Med 60: 89-97.

GOMEZ-GUZMAN M ET AL. 2012. Epicatechin lowers blood pressure, restores endothelial function, and decreases oxidative stress and endothelin-1 and NADPH oxidase activity in DOCA-salt hypertension. Free Radical Bio Med 52: 70-79.

GRACE M, ESPOSITO D, TIMMERS M AND LILA MA. 2015. Phytochemical Characterization, Anti-inflammatory and Lipolytic Activities of Pistachio Hulls, Skins, and Kernels. The FASEB J 29.

GRASSI D, NECOZIONE S, LIPPI C, CROCE G, VALERI L, PASQUALETTI P, DESIDERI G, BLUMBERG JB AND FERRI C. 2005. Cocoa reduces blood pressure and insulin resistance and improves endothelium-dependent vasodilation in hypertensives. Hypertension 46: 398-405.

GUASCH-FERRE M ET AL. 2014. Olive oil intake and risk of cardiovascular disease and mortality in the PREDIMED Study. BMC Medicine 12: 78.

HADI HA, CARR CS AND AL SUWAIDI J. 2005. Endothelial dysfunction: cardiovascular risk factors, therapy, and outcome. Vasc Health Risk Manag 1: 183-198.

HASSELLUND SS, FLAA A, KJELDSEN SE, SELJEFLOT I, KARLSEN A, ERLUND I AND ROSTRUP M. 2013. Effects of anthocyanins on cardiovascular risk factors and inflammation in pre-hypertensive men: a double-blind randomized placebo-controlled crossover study. J Hum Hypertens 27: 100-106. 
HEITZER T, SCHLINZIG T, KROHN K, MEINERTZ T AND MUNZEL T. 2001. Endothelial dysfunction, oxidative stress, and risk of cardiovascular events in patients with coronary artery disease. Circulation 104: 2673-2678.

HIGASHINO S, SASAKI Y, GIDDINGS JC, HYODO K, FUJIMOTO SAKATA S, MATSUDA K, HORIKAWA Y AND YAMAMOTO J. 2014. Crocetin, a Carotenoid from Gardenia jasminoides Ellis, Protects against Hypertension and Cerebral Thrombogenesis in Strokeprone Spontaneously Hypertensive Rats. Phytother Res, PTR 28: 1315-1319.

HOBBS DA, GOULDING MG, NGUYEN A, MALAVER T, WALKER CF, GEORGE TW, METHVEN L AND LOVEGROVE JA. 2013. Acute ingestion of beetroot bread increases endothelium-independent vasodilation and lowers diastolic blood pressure in healthy men: a randomized controlled trial. J Nutr 143: 1399-1405.

HOLLANDS WJ, HART DJ, DAINTY JR, HASSELWANDER O, TIIHONEN K, WOOD R AND KROON PA. 2013. Bioavailability of epicatechin and effects on nitric oxide metabolites of an apple flavanol-rich extract supplemented beverage compared to a whole apple puree: a randomized, placebo-controlled, crossover trial. Mol Nutr Food Res 57: 1209-1217.

HORN P, AMABILE N, ANGELI FS, SANSONE R, STEGEMANN B, KELM M, SPRINGER ML, YEGHIAZARIANS Y, SCHROETER H AND HEISS C. 2014. Dietary flavanol intervention lowers the levels of endothelial microparticles in coronary artery disease patients. BR J Nutr 111: 1245-1252.

HUANG W, ZHU Y, LI C, SUI Z AND MIN W. 2016. Effect of Blueberry Anthocyanins Malvidin and Glycosides on the Antioxidant Properties in Endothelial Cells. Oxid Med Cell Longev 2016: 1591803.

ICAZA G, NUNEZ L, MARRUGAT J, MUJICA V, ESCOBAR MC, JIMENEZ AL, PEREZ P AND PALOMO I. 2009. Estimation of coronary heart disease risk in Chilean subjects based on adapted Framingham equations. Rev Med Chil 137: 1273-1282.

JIMENEZ R, DUARTE J AND PEREZ-VIZCAINO F. 2012. Epicatechin: endothelial function and blood pressure. $\mathrm{J}$ Agr Food Chem 60: 8823-8830.

JORIS PJ AND MENSINK RP. 2013. Beetroot juice improves in overweight and slightly obese men postprandial endothelial function after consumption of a mixed meal. Atherosclerosis 231: 78-83.

KANAJI S, FAHS SA, SHI Q, HABERICHTER SL AND MONTGOMERY RR. 2012. Contribution of platelet vs. endothelial VWF to platelet adhesion and hemostasis. J Thromb Haemost 10: 1646-1652.

KATZ DL, DAVIDHI A, MA Y, KAVAK Y, BIFULCO L AND NJIKE VY. 2012. Effects of walnuts on endothelial function in overweight adults with visceral obesity: a randomized, controlled, crossover trial. J Am Coll Nutr 31: 415-423.

KAWAKAMI K, AKETA S, SAKAI H, WATANABE Y, NISHIDA H AND HIRAYAMA M. 2011. Antihypertensive and vasorelaxant effects of water-soluble proanthocyanidins from persimmon leaf tea in spontaneously hypertensive rats. Biosci Biotech Bioch 75: 1435-1439.

KELISHADI R, GIDDING SS, HASHEMI M, HASHEMIPOUR M, ZAKERAMELI A AND POURSAFA P. 2011. Acute and long term effects of grape and pomegranate juice consumption on endothelial dysfunction in pediatric metabolic syndrome. J Res Med Sci: the official journal of Isfahan University of Medical Sciences 16: 245-253.

KIM HS, MONTANA V, JANG HJ, PARPURA V AND KIM JA. 2013a. Epigallocatechin gallate (EGCG) stimulates autophagy in vascular endothelial cells: a potential role for reducing lipid accumulation. J Biol Chem 288: 22693 22705.

KIM K, LIM KM, SHIN HJ, SEO DB, NOH JY, KANG S, CHUNG HY, SHIN S, CHUNG JH AND BAE ON. 2013b. Inhibitory effects of black soybean on platelet activation mediated through its active component of adenosine. Thromb Res 131: 254-261.

KOZLOWSKA A AND SZOSTAK-WEGIEREK D. 2014. Flavonoids--food sources and health benefits. Rocz Panstw Zakl Hig 65: 79-85.

LAMY S, BLANCHETTE M, MICHAUD-LEVESQUE J, LAFLEUR R, DUROCHER Y, MOGHRABI A, BARRETTE S, GINGRAS D AND BELIVEAU R. 2006. Delphinidin, a dietary anthocyanidin, inhibits vascular endothelial growth factor receptor-2 phosphorylation. Carcinogenesis 27: 989-996.

LEE HS, LEE MJ, KIM H, CHOI SK, KIM JE, MOON HI AND PARK WH. 2010. Curcumin inhibits TNF alphainduced lectin-like oxidised LDL receptor-1 (LOX-1) expression and suppresses the inflammatory response in human umbilical vein endothelial cells (HUVECs) by an antioxidant mechanism. J Enzyme Inhib Med Chem 25: 720-729.

LEE J, JUNG Y, SHIN JH, KIM HK, MOON BC, RYU DO H AND HWANG GS. 2014. Secondary Metabolite Profiling of Curcuma Species Grown at Different Locations Using GC/TOF and UPLC/Q-TOF MS. Molecules 19: 9535-9551.

LEIFERT WR AND ABEYWARDENA MY. 2008. Cardioprotective actions of grape polyphenols. Nutr Res 28: 729-737.

LI J, YE L, WANG X, LIU J, WANG Y, ZHOU Y AND HO W. 2012. (-)-Epigallocatechin gallate inhibits endotoxininduced expression of inflammatory cytokines in human cerebral microvascular endothelial cells. J Neuroinflammation 9: 161.

LI KWOK CHEONG JD, CROFT KD, HENRY PD, MATTHEWS V, HODGSON JM AND WARD NC. 2014. 
Green coffee polyphenols do not attenuate features of the metabolic syndrome and improve endothelial function in mice fed a high fat diet. Arch Bbiochem Biophys 559: 46-52.

LI RW, YANG C, SIT AS, KWAN YW, LEE SM, HOI MP, CHAN SW, HAUSMAN M, VANHOUTTE PM AND LEUNG GP. 2014. Uptake and protective effects of ergothioneine in human endothelial cells. J Pharmacol Exp Ther 350: 691-700.

LILA MA. 2004. Anthocyanins and Human Health: An in vitro Investigative Approach. J Biomed Biotechnol 2004: 306-313.

LIM KH ET AL. 2012. Assessment of antidiabetogenic potential of fermented soybean extracts in streptozotocininduced diabetic rat. Food Chem Toxicol: an International Journal published for the British Industrial Biological Research Association 50: 3941-3948.

LIU J, SUI X, LAVIE CJ, HEBERT JR, EARNEST CP, ZHANG J AND BLAIR SN. 2013. Association of coffee consumption with all-cause and cardiovascular disease mortality. Mayo Clinic proceedings 88: 1066-1074.

LIU S, MANSON JE, LEE IM, COLE SR, HENNEKENS CH, WILLETT WC AND BURING JE. 2000. Fruit and vegetable intake and risk of cardiovascular disease: the Women's Health Study. Am J Clin Nutr 72: 922-928.

LOOMBA RS, AGGARWAL S AND ARORA RR. 2014. The Effect of Coffee and Quantity of Consumption on Specific Cardiovascular and All-Cause Mortality: Coffee Consumption Does Not Affect Mortality. Am J Ther 23: e232-237.

MACREADY AL ET AL. 2014. Flavonoid-rich fruit and vegetables improve microvascular reactivity and inflammatory status in men at risk of cardiovascular disease--FLAVURS: a randomized controlled trial. Am J Clin Nutr 99: 479-489.

MAHMOUD MF, HASSAN NA, EL BASSOSSY HM AND FAHMY A. 2013. Quercetin protects against diabetesinduced exaggerated vasoconstriction in rats: effect on low grade inflammation. PloS one 8: e63784.

MANACH C, WILLIAMSON G, MORAND C, SCALBERT AAND REMESY C. 2005. Bioavailability and bioefficacy of polyphenols in humans. I. Review of 97 bioavailability studies. Am J Clin Nutr 81: 230S-242S.

MARTIN KR. 2010. The bioactive agent ergothioneine, a key component of dietary mushrooms, inhibits monocyte binding to endothelial cells characteristic of early cardiovascular disease. J Med Food 13: 1340-1346.

MARTINEZ-GONZALEZ MA, DOMINGUEZ LJ AND DELGADO-RODRIGUEZ M. 2014a. Olive oil consumption and risk of CHD and/or stroke: a metaanalysis of case-control, cohort and intervention studies. BR J Nutr 112: 248-259.

MARTINEZ-GONZALEZ MA ET AL. 2014b. Extravirgin Olive Oil Consumption Reduces Risk of Atrial Fibrillation:
The PREDIMED (Prevencion con Dieta Mediterranea) Trial. Circulation 130: 18-26.

MATSUMOTO T, WATANABE S, KAWAMURA R, TAGUCHI K AND KOBAYASHI T. 2013. Epigallocatechin gallate attenuates ET-1-induced contraction in carotid artery from type 2 diabetic OLETF rat at chronic stage of disease. Life Sci 118: 200-205.

MINATTI J, WAZLAWIK E, HORT MA, ZALESKI FL, RIBEIRO-DO-VALLE RM, MARASCHIN M AND DA SILVA EL. 2012. Green tea extract reverses endothelial dysfunction and reduces atherosclerosis progression in homozygous knockout low-density lipoprotein receptor mice. Nutr Res 32: 684-693.

MIRÓ-CASAS E, COVAS MI, FITO M, FARREALBADALEJO M, MARRUGAT J AND DE LA TORRE R. 2003. Tyrosol and hydroxytyrosol are absorbed from moderate and sustained doses of virgin olive oil in humans. Eur J Clin Nutr 57: 186-190.

MIRÓ-CASAS E, FARRE ALBADALEJO M, COVAS PLANELLS MI, FITO COLOMER M, LAMUELA RAVENTOS RM AND DE LA TORRE FORNELL R. 2001. Tyrosol bioavailability in humans after ingestion of virgin olive oil. Clin Chem 47: 341-343.

MORAND C, DUBRAY C, MILENKOVIC D, LIOGER D, MARTIN JF, SCALBERT A AND MAZUR A. 2011. Hesperidin contributes to the vascular protective effects of orange juice: a randomized crossover study in healthy volunteers. Am J Clin Nutr 93: 73-80.

MORDENTEA, GUANTARIO B, MEUCCIE, SILVESTRINI A, LOMBARDI E, MARTORANA GE, GIARDINA B AND BOHM V. 2011. Lycopene and cardiovascular diseases: an update. Curr Med Chem 18: 1146-1163.

MORENO-LUNA R, MUNOZ-HERNANDEZ R, MIRANDA ML, COSTA AF, JIMENEZ-JIMENEZ L, VALLEJOVAZ AJ, MURIANA FJ, VILLAR J AND STIEFEL P. 2012. Olive oil polyphenols decrease blood pressure and improve endothelial function in young women with mild hypertension. Am J Hypertens 25: 1299-1304.

MORENO-ULLOA A, ROMERO-PEREZ D, VILLARREAL F, CEBALLOS G AND RAMIREZ-SANCHEZ I. 2014. Cell membrane mediated (-)-epicatechin effects on upstream endothelial cell signaling: evidence for a surface receptor. Bioorg Med Chem Lett 24: 2749-2752.

MUBARAK A, BONDONNO CP, LIU AH, CONSIDINE MJ, RICH L, MAS E, CROFT KD AND HODGSON JM. 2012. Acute effects of chlorogenic acid on nitric oxide status, endothelial function, and blood pressure in healthy volunteers: a randomized trial. J Agr Food Chem 60: 9130-9136.

MUJICA V, LEIVA E, ICAZA G, DIAZ N, ARREDONDO M, MOORE-CARRASCO R, ORREGO R, VASQUEZ M AND PALOMO I. 2008. Evaluation of metabolic syndrome in adults of Talca city, Chile. Nutr J 7: 14.

NAGAO T, KOMINE Y, SOGA S, MEGURO S, HASE T, TANAKA Y AND TOKIMITSU I. 2005. Ingestion of a 
tea rich in catechins leads to a reduction in body fat and malondialdehyde-modified LDL in men. Am J Clin Nutr 81: 122-129.

NAKAYAMA H, TSUGE N, SAWADA H AND HIGASHI Y. 2013. Chronic intake of onion extract containing quercetin improved postprandial endothelial dysfunction in healthy men. J Am Coll Nutr 32: 160-164.

NOLL C, LAMETH J, PAUL JL AND JANEL N. 2013. Effect of catechin/epicatechin dietary intake on endothelial dysfunction biomarkers and proinflammatory cytokines in aorta of hyperhomocysteinemic mice. Eur J Nutr 52: 1243-1250.

O’DONNELL CJ AND ELOSUA R. 2008. Cardiovascular risk factors. Insights from Framingham Heart Study. Rev Esp Cardiol 61: 299-310.

OREM A, YUCESAN FB, OREM C, AKCAN B, KURAL BV, ALASALVAR C AND SHAHIDI F. 2013. Hazelnutenriched diet improves cardiovascular risk biomarkers beyond a lipid-lowering effect in hypercholesterolemic subjects. J Clin Lipidol 7: 123-131.

OSAKABE N AND SHIBATA M. 2012. Ingestion of cocoa ameliorates endothelial dysfunction in mesentery arterioles induced by high fat diet in rats: an in vivo intravital microscopy study. Life Sci 91: 1196-1200.

PALOMO GI, ICAZA NG, MUJICA EV, NUNEZ FL, LEIVA ME, VASQUEZ RM, ALARCON LM AND MOYANO DE. 2007. Prevalence of cardiovascular risk factors in adult from Talca, Chile. Rev Med Chil 135: 904-912.

PALOMO I, CONTRERAS A, ALARCON LM, LEIVA E, GUZMAN L, MUJICA V, ICAZA G, DIAZ N, GONZALEZ DR AND MOORE-CARRASCO R. 2011. Elevated concentration of asymmetric dimethylarginine (ADMA) in individuals with metabolic syndrome. Nitric Oxide 24: 224-228.

PALOMO I, MARIN P, ALARCON M, GUBELIN G, VINAMBRE X, MORA E AND ICAZA G. 2003. Patients with essential hypertension present higher levels of sEselectin and SVCAM-1 than normotensive volunteers. Clin Exp Hypertens 25: 517-523.

PALOMO IF, TORRES GI, ALARCON MA, MARAGANO PJ, LEIVA E AND MUJICA V. 2006. High prevalence of classic cardiovascular risk factors in a population of university students from south central Chile. Rev Esp Cardiol 59: 1099-1105.

PERI L, PIETRAFORTE D, SCORZA G, NAPOLITANO A, FOGLIANO V AND MINETTI M. 2005. Apples increase nitric oxide production by human saliva at the acidic $\mathrm{pH}$ of the stomach: a new biological function for polyphenols with a catechol group? Free Radical Bio Med 39: 668-681.

PERVEEN R, SULERIA HA, ANJUM FM, BUTT MS, PASHA I AND AHMAD S. 2013. Tomato (Solanum lycopersicum) carotenoids \& lycopenes chemistry;
Metabolism, absorption, nutrition and allied health claimsA comprehensive review. Cr Rev Food Sci 55: 919-929.

PETERS CM, GREEN RJ, JANLE EM AND FERRUZZI MG. 2010. Formulation with ascorbic acid and sucrose modulates catechin bioavailability from green tea. Food Res Int 43: 95-102.

PUSPARINI, DHARMAR, SUYATNAFD, MANSYUR MAND HIDAJAT A. 2013. Effect of soy isoflavone supplementation on vascular endothelial function and oxidative stress in postmenopausal women: a community randomized controlled trial. Asia Pac J Clin Nutr 22: 357-364.

QUINTIERI AM, BALDINO N, FILICE E, SETA L, VITETTI A, TOTA B, DE CINDIO B, CERRA MC AND ANGELONE T. 2013. Malvidin, a red wine polyphenol, modulates mammalian myocardial and coronary performance and protects the heart against ischemia/ reperfusion injury. J Nutr Biochem 24: 1221-1231.

RAHIM SM, TAHA EM, MUBARK ZM, AZIZ SS, SIMON KD AND MAZLAN AG. 2013. Protective effect of Cymbopogon citratus on hydrogen peroxide-induced oxidative stress in the reproductive system of male rats. Syst Biol Reprod Med 59: 329-336.

REBHOLZ CM, REYNOLDS K, WOFFORD MR, CHEN J, KELLY TN, MEI H, WHELTON PK AND HE J. 2013. Effect of soybean protein on novel cardiovascular disease risk factors: a randomized controlled trial. Eur J Clin Nutr 67: 58-63.

ROS E, MARTINEZ-GONZALEZ MA, ESTRUCH R, SALAS-SALVADO J, FITO M, MARTINEZ JA AND CORELLAD. 2014. Mediterranean diet and cardiovascular health: Teachings of the PREDIMED study. Adv Nutr 5: 330S-336S.

ROS E, NUNEZ I, PEREZ-HERAS A, SERRA M, GILABERT R, CASALS E AND DEULOFEU R. 2004. A walnut diet improves endothelial function in hypercholesterolemic subjects: a randomized crossover trial. Circulation 109: 1609-1614.

RUGGERI ZM. 1997. Mechanisms initiating platelet thrombus formation. Thromb Haemost 78: 611-616.

RUNGSEESANTIVANON S, THENCHAISRI N, RUANGVEJVORACHAI P AND PATUMRAJ S. 2010. Curcumin supplementation could improve diabetesinduced endothelial dysfunction associated with decreased vascular superoxide production and PKC inhibition. BMC Complement Altern Med 10: 57.

SALAS-SALVADO J, GUASCH-FERRE M, BULLO M AND SABATE J. 2014. Nuts in the prevention and treatment of metabolic syndrome. Am J Clin Nutr 100: 399S-407S.

SANO S, SUGIYAMA K, ITO T, KATANO Y AND ISHIHATA A. 2011. Identification of the strong vasorelaxing substance scirpusin B, a dimer of piceatannol, from passion fruit (Passiflora edulis) seeds. J Agr Food Chem 59: 6209-6213. 
SARI I, BALTACI Y, BAGCI C, DAVUTOGLU V, EREL O, CELIK H, OZER O, AKSOY N AND AKSOY M. 2010. Effect of pistachio diet on lipid parameters, endothelial function, inflammation, and oxidative status: a prospective study. Nutrition 26: 399-404.

SAUDER KA, MCCREA CE, ULBRECHT JS, KRISETHERTON PM AND WEST SG. 2014. Pistachio nut consumption modifies systemic hemodynamics, increases heart rate variability, and reduces ambulatory blood pressure in well-controlled type 2 diabetes: a randomized trial. J Am Heart Assoc 3: e000873.

SCHINI-KERTH VB, ETIENNE-SELLOUM N, CHATAIGNEAU T AND AUGER C. 2011. Vascular protection by natural product-derived polyphenols: in vitro and in vivo evidence. Planta Medica 77: 1161-1167.

SERRA AT, ROCHA J, SEPODES B, MATIAS AA, FELICIANO RP, DE CARVALHO A, BRONZE MR, DUARTE CM AND FIGUEIRA ME. 2012. Evaluation of cardiovascular protective effect of different apple varieties - Correlation of response with composition. Food Chem 135: 2378-2386.

SHEN Y, WARD NC, HODGSON JM, PUDDEY IB, WANG Y, ZHANG D, MAGHZAL GJ, STOCKER R AND CROFT KD. 2013. Dietary quercetin attenuates oxidantinduced endothelial dysfunction and atherosclerosis in apolipoprotein E knockout mice fed a high-fat diet: a critical role for heme oxygenase-1. Free Radical Bio Med 65: 908-915.

SHI J AND LE MAGUER M. 2000. Lycopene in tomatoes: chemical and physical properties affected by food processing. Crit Rev Biotechnol 20: 293-334.

SILVA DC, FREITAS AL, PESSOA CD, PAULA RC, MESQUITA JX, LEAL LK, BRITO GA, GONCALVES DO AND VIANA GS. 2011. Pectin from Passiflora edulis shows anti-inflammatory action as well as hypoglycemic and hypotriglyceridemic properties in diabetic rats. J Med Food 14: 1118-1126.

SOARES MO, ALVES RC, PIRES PC, OLIVEIRA MB AND VINHA AF. 2013. Angolan Cymbopogon citratus used for therapeutic benefits: nutritional composition and influence of solvents in phytochemicals content and antioxidant activity of leaf extracts. Food Chem Toxicol: an international journal published for the British Industrial Biological Research Association 60: 413-418.

SON JE, HWANG MK, LEE E, SEO SG, KIM JE, JUNG SK, KIM JR, AHN GH, LEE KW AND LEE HJ. 2013. Persimmon peel extract attenuates PDGF-BB-induced human aortic smooth muscle cell migration and invasion through inhibition of c-Src activity. Food Chem 141: 3309-3316.

SUGIYAMA K ET AL. 2010. Coffee consumption and mortality due to all causes, cardiovascular disease, and cancer in Japanese women. J Nutr 140: 1007-1013.
TADDEI S, GHIADONI L, VIRDIS A, VERSARI D AND SALVETTI A. 2003. Mechanisms of endothelial dysfunction: clinical significance and preventive nonpharmacological therapeutic strategies. Curr Pharm Des 9: 2385-2402.

TAGLIAFERRI C ET AL. 2014. Olive oil and vitamin D synergistically prevent bone loss in mice. PloS one 9: e115817.

TANAKA Y, SASAKI N AND OHMIYA A. 2008. Biosynthesis of plant pigments: anthocyanins, betalains and carotenoids. Plant J 54: 733-749.

TAPSELL LC. 2014. Foods and food components in the Mediterranean diet: supporting overall effects. BMC Medicine 12: 100.

TEY SL, BROWN RC, CHISHOLM AW, DELAHUNTY CM, GRAY AR AND WILLIAMS SM. 2011. Effects of different forms of hazelnuts on blood lipids and alphatocopherol concentrations in mildly hypercholesterolemic individuals. Eur J Clin Nutr 65: 117-124.

TEY SL, GRAY AR, CHISHOLM AW, DELAHUNTY CM AND BROWN RC. 2013. The dose of hazelnuts influences acceptance and diet quality but not inflammatory markers and body composition in overweight and obese individuals. J Nutr 143: 1254-1262.

TOMAINO A, MARTORANA M, ARCORACI T, MONTELEONE D, GIOVINAZZO C AND SAIJA A. 2010. Antioxidant activity and phenolic profile of pistachio (Pistacia vera L., variety Bronte) seeds and skins. Biochimie 92: 1115-1122.

TROPED PJ, WILSON JS, MATTHEWS CE, CROMLEY EK AND MELLY SJ. 2010. The Built Environment and Location-Based Physical Activity. Am J Prev Med 38: 429-438.

TSAI YM, CHANG-LIAO WL, CHIEN CF, LIN LC AND TSAI TH. 2012. Effects of polymer molecular weight on relative oral bioavailability of curcumin. Int $\mathrm{J}$ Nanomedicine 7: 2957-2966.

TUNALI-AKBAY T, SEHIRLI O, ERCAN F AND SENER G. 2010. Resveratrol protects against methotrexate-induced hepatic injury in rats. J Pharm Pharm Sci: a publication of the Canadian Society for Pharmaceutical Sciences, Societe canadienne des sciences pharmaceutiques 13: 303-310.

UMIGAI N, TANAKA J, TSURUMA K, SHIMAZAWA M AND HARA H. 2012. Crocetin, a carotenoid derivative, inhibits VEGF-induced angiogenesis via suppression of p38 phosphorylation. Curr Neurovasc Res 9: 102-109.

VALERO-MUNOZ M, MARTIN-FERNANDEZ B, BALLESTEROS S, DE LA FUENTE E, QUINTELA JC, LAHERA V AND DE LAS HERAS N. 2014. Protective effect of a pomace olive oil concentrated in triterpenic acids in alterations related to hypertension in rats: mechanisms involved. Mol Nutr Food Res 58: 376-383.

VARALAKSHMI C, ALI AM, PARDHASARADHI BV, SRIVASTAVA RM, SINGH S AND KHAR A. 2008. 
Immunomodulatory effects of curcumin: in-vivo. Int Immunopharmacol 8: 688-700.

VERSARI D, DAGHINI E, VIRDIS A, GHIADONI L AND TADDEI S. 2009. Endothelial dysfunction as a target for prevention of cardiovascular disease. Diabetes Care 32(Suppl 2): S314-321.

WALLE T, HSIEH F, DELEGGE MH, OATIS JR JE AND WALLE UK. 2004. High absorption but very low bioavailability of oral resveratrol in humans. Drug metabolism and disposition: The Biological Fate of Chemicals 32: 1377-1382.

WANG JP, XU HX, WU YX, YE YJ, RUAN JL, XIONG CM AND CAI YL. 2011. Ent-16beta,17-dihydroxy-kauran19-oic acid, a kaurane diterpene acid from Siegesbeckia pubescens, presents antiplatelet and antithrombotic effects in rats. Phytomedicine: International Journal of Phytotherapy and Phytopharmacology 18: 873-878.

WANG R, LIU YQ, HA W, SHI YP, HWANG TL, HUANG GJ, WU TS AND LEE KH. 2014. In vitro anti-inflammatory effects of diterpenoids and sesquiterpenoids from traditional Chinese medicine Siegesbeckia pubescens. Bioorgan Med Chem Lett 24: 3944-3947.

WATSON RR AND SCHONLAU F. 2015. Nutraceutical and antioxidant effects of a delphinidin-rich maqui berry extract Delphinol(R): a review. Minerva Cardioangiol 63: $1-12$.

WEST SG, MCINTYRE MD, PIOTROWSKI MJ, POUPIN N, MILLER DL, PRESTON AG, WAGNER P, GROVES LF AND SKULAS-RAY AC. 2014. Effects of dark chocolate and cocoa consumption on endothelial function and arterial stiffness in overweight adults. BR J Nutr 111: 653-661.

WONG YS, SIA CM, KHOO HE, ANG YK, CHANG SK, CHANG SK AND YIM HS. 2014. Influence of extraction conditions on antioxidant properties of passion fruit (Passiflora edulis) peel. Acta Sci Pol Technol Aliment 13: 257-265.

WOODCOCK ME, HOLLANDS WJ, KONIC-RISTIC A, GLIBETIC M, BOYKO N, KOCAOGLU B AND KROON PA. 2013. Bioactive-rich extracts of persimmon, but not nettle, Sideritis, dill or kale, increase eNOS activation and NO bioavailability and decrease endothelin-1 secretion by human vascular endothelial cells. J Sci Food Agr 93: 3574-3580.

WOODWARD G, KROON P, CASSIDY A AND KAY C. 2009. Anthocyanin stability and recovery: implications for the analysis of clinical and experimental samples. J Agr Food Chem 57: 5271-5278.

WU L ET AL. 2014. Walnut-enriched diet reduces fasting nonHDL-cholesterol and apolipoprotein B in healthy Caucasian subjects: a randomized controlled cross-over clinical trial. Metabolism: clinical and experimental 63: 382-391.

WU PT, FITSCHEN PJ, KISTLER BM, JEONG JH, CHUNG HR, AVIRAM M, PHILLIPS SA, FERNHALL B AND
WILUND KR. 2015. Effects of Pomegranate Extract Supplementation on Cardiovascular Risk Factors and Physical Function in Hemodialysis Patients. J Med Food 18: 941-949.

XAPLANTERIS P, VLACHOPOULOS C, PIETRI $\mathrm{P}$, TERENTES-PRINTZIOS D, KARDARA D, ALEXOPOULOS N, AZNAOURIDIS K, MILIOU A AND STEFANADIS C. 2012. Tomato paste supplementation improves endothelial dynamics and reduces plasma total oxidative status in healthy subjects. Nutr Res 32: 390-394.

XU C, CHEN J, ZHANG J, HU X, ZHOU X, LU Z AND JIANG H. 2013. Naringenin inhibits angiotensin IIinduced vascular smooth muscle cells proliferation and migration and decreases neointimal hyperplasia in balloon injured rat carotid arteries through suppressing oxidative stress. Biol Pharm Bull 36: 1549-1555.

YAPO BM AND KOFFI KL. 2006. Yellow passion fruit rind-a potential source of low-methoxyl pectin. J Agr Food Chem 54: 2738-2744.

YURDAGUL JR A, KLEINEDLER JJ, MCINNIS MC, KHANDELWAL AR, SPENCE AL, ORR AW AND DUGAS TR. 2014. Resveratrol promotes endothelial cell wound healing under laminar shear stress through an estrogen receptor-alpha-dependent pathway. Am J Physiol Heart Circ Physiol 306: H797-806.

ZARFESHANY A, ASGARY S AND JAVANMARD SH. 2014. Potent health effects of pomegranate. Adv biomed Res 3: 100.

ZERAIK ML, SERTEYN D, DEBY-DUPONT G, WAUTERS JN, TITS M, YARIWAKE JH, ANGENOT L AND FRANCK T. 2011. Evaluation of the antioxidant activity of passion fruit (Passiflora edulis and Passiflora alata) extracts on stimulated neutrophils and myeloperoxidase activity assays. Food Chem 128: 259-265.

ZERN TL AND FERNANDEZ ML. 2005. Cardioprotective effects of dietary polyphenols. J Nutr 135: 2291-2294.

ZHANG W, LOPEZ-GARCIA E, LI TY, HU FB AND VAN DAM RM. 2009. Coffee consumption and risk of cardiovascular diseases and all-cause mortality among men with type 2 diabetes. Diabetes Care 32: 1043-1045.

ZHANG Y, SHI H, WANG W, KE Z, XU P, ZHONG Z, LI $X$ AND WANG S. 2011. Antithrombotic effect of grape seed proanthocyanidins extract in a rat model of deep vein thrombosis. J Vasc Surg 53: 743-753.

ZIBERNA L, KIM JH, AUGER C, PASSAMONTI S AND SCHINI-KERTH V. 2013. Role of endothelial cell membrane transport in red wine polyphenols-induced coronary vasorelaxation: involvement of bilitranslocase. Food Funct 4: 1452-1456.

\section{SUPPLEMETARY MATERIAL}

Table SI - Endothelial cell protection and natural bioactive compounds. 